\title{
PENGARUH DISIPLIN, KEPUASAN KERJA DAN MOTIVASI TERHADAP PRODUKTIVITAS KERJA PEGAWAI SEKRETARIAT DAERAH KOTA TANJUNGBALAI
}

\author{
${ }^{1}$ Hurmaini Nasution, ${ }^{2}$ Evi Rahmwati, ${ }^{3}$ Three Indra Bakti, ${ }^{4}$ Alboin Adarian, ${ }^{5}$ Ajimi \\ $1,2,3,4,5$ Universitas Islam Sumatera Utara \\ I'hurmaini.nst@gmail.com, ${ }^{2}$ evi.rahmawati@gmail.com, ${ }^{3}$ three.indra@gmail.com, ${ }^{4}$ alboin.adrian@gmail.com, \\ 5 ajimi.mm@gmail.com
}

\begin{abstract}
The formulation of the problem in this research is: Do discipline, job satisfaction and motivation affect the work productivity of employees at Sekretariat Daerah Kota Tanjungbalai. This study aims to determine the effect of job satisfaction and motivation on employee productivity. With total sampling technique, the sample in this study was 36 people. The results showed; Discipline partially has a positive effect on employee work productivity; Job satisfaction partially has a positive effect on employee work productivity; Motivation partially has a positive effect on employee work productivity; Discipline, job satisfaction and motivation have a positive and significant effect on employee work productivity.
\end{abstract}

Keywords : Discipline; Job satisfaction; Motivation; Work productivity

ABSTRAK : Rumusan masalah dalam penelitian ini adalah : Apakah disiplin, kepuasan kerja dan motivasi berpengaruh terhadap produktivitas kerja pegawai di Sekretariat Daerah Kota Tanjungbalai. Penelitian ini bertujuan untuk mengetahui pengaruh kepuasan kerja dan motivasi berpengaruh terhadap produktivitas kerja pegawai. Dengan teknik penarikan sampel secara Total Sampling maka sampel dalam penelitian ini sebanyak 36 orang. Hasil penelitian menunjukkan; Disiplin secara parsial berpengaruh positif terhadap produktivitas kerja pegawai; Kepuasan kerja secara parsial berpengaruh positif terhadap produktivitas kerja pegawai; Motivasi secara parsial berpengaruh positif terhadap produktivitas kerja pegawai; Disiplin, kepuasan kerja dan motivasi berpengaruh positif dan signifikan terhadap produktivitas kerja pegawai.

Kata Kunci : Disiplin; Kepuasan Kerja; Motivasi; Produktivitas Kerja

\section{Pendahuluan}

Produktivitas kerja pegawai pada sebuah instansi merupakan masalah yang selalu hangat dan tidak ada habis-habisnya untuk dibahas. Permasalahan yang terkait dalam produktifitas juga merupakan isu strategis bagi instansi yang memprogram masalah sumber daya manusia. Banyak aspek intenal dan eksternal yang mendukung terciptanya produktivitas kerja yang efektif dan efisien dalam suatu instansi. Apalagi bila dikaitkan dengan masalah globalisasi yang melanda saat ini yang dampaknya sangat kita rasakan.

Organisasi perlu dikembangkan dengan memperhatikan pegawai dan terus mempertimbangkan perasaan dan sikap manusia. Berdasarkan teori hubungan manusia fungsi pemimpin adalah memudahkan pencapaian tujuan secara kolektif diantara para pengikut dan pada saat yang sama menyediakan kesempatan dan pertumbuhan serta perkembangan bagi pribadi mereka.

Produktivitas kerja merupakan syarat utama bagi instansi dalam menghadapi persaingan serta peningkatan pendapatan instansi. Produktivitas tenaga kerja merupakan suatu kaitan antara output yakni hasil kerja dengan waktu yang dibutuhkan untuk menghasilkan produk oleh seorang tenaga kerja. Produktivitas merupakan salah satu ukuran yang sering dipakai dalam menentukan efektivitas organisasi. Sebuah organisasi atau instansi tidak akan dapat berkembang apabila produktivitas kerja pegawainya juga tidak mengalami peningkatan apalagi dengan semakin tingginya tingkat persaingan yang ada dalam dunia pekerjaan. Peningkatan kualitas dan 
produktivitas adalah kata kunci (keywords) untuk dapat mengejar ketinggalan sehingga mampu bersaing bukan hanya ditataran regional dan nasional, tetapi juga di level global. Peningkatan kualitas dan produktivitas harus dilakukan secara terus menerus, baik pada tataran makro maupun mikro, baik ditingkat pusat maupun daerah.

Sebuah penelitian yang dilakukan oleh Chukwuma, Maduka dan Okafor (2014:138) mengenai produktivitas pegawai di industry manufaktur menyatakan bahwa pegawai adalah asset penting bagi instansi yang berpengaruh dalam keberlangsungan instansi. Industri manufakur di Newi sulit berkembang karena produktivitas pegawai yang rendah sehingga sulit besaing. Sedangkan menurut penelitian yang dilakukan oleh Verde (2014:5-7) menyatakan bahwa industri garmen di negara Bangladesh dan Kamboja terus berkembang karena selalu memperhatikan dan menjaga produktivitas kerja para pegawainya karena jika produktivitas pegawainya rendah maka akan menimbulkan masalah yang berpengaruh terhadap market share.

Produktivitas kerja pegawai sangat penting bagi instansi dalam rangka persaingan bisnis yang kompetitif dan berpengaruh terhadap keberlangsungan instansi dalam mencapai tujuan. Menurut Crook et. Al (2011:261262) menyebutkan bahwa produktivitas mencakup dua konsep dasar yaitu daya guna dan hasil guna. Daya guna menggambarkan tingkat sumber daya manusia, dana, dan alam yang diperlukan untuk mengusahakan hasil tertentu, sedangkan hasil guna menggambarkan akibat dan kualitas dari hasil yang diusahakan. Menurut Guion (2011:139) menyatakan dengan produktivitas yang tinggi, maka pencapaian tujuan instansi dapat dicapai semaksimal mungkin.

\begin{tabular}{llrr}
\multicolumn{1}{c}{ Produktivitas kerja yang } & rendah \\
merupakan masalah & $\begin{array}{r}\text { yang } \\
\text { harus } \\
\text { diselesaikan }\end{array}$ oleh & instansi & karena
\end{tabular} diselesaikan oleh instansi karena produktivitas pegawai dapat mempengaruhi menghadapi persaingan dan menjadi kunci utama dalam mencapai tujuan instansi. Permasalahan tersebut sering terjadi dan tidak boleh terus dibiarkan apabila instansi ingin terus berkembang. Permasalahan produktivitas kerja dialami juga di instansi Sekretariat Daerah Kota Tanjungbalai yang sedang menghadapi permasalahan internal seperti rendahnya kualiitas hasil kerja dan target dari instansi tidak tercapai padahal Sekretariat Daerah Kota Tanjungbalai sudah mencanangkan program kerja yang sangat tinggi, maka dari itu Sekretariat Daerah Kota Tanjungbalai mempunyai tuntutan yang tinggi akan produktivitas kerja para pegawainya.

Dari survey awal yang di lakukan peneliti mendapatkan beberapa faktor yang di anggap menjadi permasalahan terhadap produktivitas kerja di Sekretariat Daerah Kota Tanjungbalai meliputi disiplin, kepuasan kerja dan motivasi. Bila ditinjau dari sudut keperilakuan, meningkatkan produktivitas manusia dalam organisasi tidak hanya menyangkut masalah penjadwalan pekerjaan dan ketrampilan dalam menyelesaikan pekerjaan tetapi juga menyangkut kondisi dan suasana kerja serta hubungan kerja yang terjalin diantara sesama anggota organisasi. Produktivitas organisasi tergantung dari produktivitas kerja secara individu, dengan demikian tergantung dari masing-masing individu dalam melaksanakan kerjanya. Dengan demikian dari survei yang di lakukan peneliti menjelaskan beberapa permasalahan yang di anggap mempengaruhi produktivitas kerja pegawai pada Sekretariat Daerah Kota Tanjungbalai yang di jadikan sebagai variabel independen dalam penelitian ini yang meliputi :

Pada Sekretariat Daerah Kota Tanjungbalai terlihat disiplin kerja para pegawainya masih belum terlihat baik, hal ini terlihat pada banyaknya pegawai yang bolos kerja, datang terlambat dan pulang lebih awal sebelum waktunya, ke tidak lengkapan atribut seragam serta beberapa pegawai juga tidak melaksanakan tugas sesuai dengan perintah yang diberikan sehingga menimbulkan dampak yang tidak baik terhadap produktivitas pegawai dalam bekerja. Selain melalui adanya tata tertib atau peraturan yang jelas, juga harus ada penjabaran tugas dan wewenang yang jelas, tata cara, atau tata kerja yang sederhana yang dapat dengan mudah diketahui oleh setiap pegawai.

Dari hasil pengamatan dalam realiatas sehari-hari pada Sekretariat Daerah Kota Tanjungbalai tentang kepuasan kerja menunjukkan :

a. Masih terdapat beberapa pegawai mencari tambahan penghasilan di luar 
jam kerja. Hal ini mengindikasikan bahwa gaji yang mereka terima belum mencukupi kebutuhan hidup sehari-hari;

b. Beberapa gejala menunjukkan bahwa pegawai merasa tidak nyaman ketika bekerja, hal ini disebabkan oleh situasi kerja yang tidak kondusif karena ada beberapa pegawai yang terlibat konflik dan berselisih paham dan sudah terjadi bertahun-tahun.

c. Adanya persepsi bahwa pelaksanaan supervisi terhadap pegawai hanya sekedar formalitas, terlihat atasan masih belum optimal dalam melakukan supervisi. Pengawas atau supervisi masih dirasakan tidak obyektif bagi sebagian pegawai sehingga mengakibatkan adanya pegawai yang mangkir;

d. Adanya persepsi beberapa pegawai merasa bahwa tugas yang diberikan bukan tugasnya, sehingga mereka cendrung melakukan tugasnya sendiri tanpa mempedulikan tugas-tugas yang lainnya;

e. Adanya persepsi dari beberapa pegawai yang merasa bahwa peluang untuk berkembang melalui jenjang karier yang lebih tinggi terasa kurang karena minimnya program-program pelatihan, jikapun ada maka harus dengan biaya sendiri.

Gejala-gejala tersebut di atas menunjukkan bahwa pada kenyataannya, kepuasan kerja yang tercipta pada Sekretariat Daerah Kota Tanjungbalai masih sangat perlu untuk di perbaiki.

Terkait dengan kendala saat bekerja, bahwa kendala yang dihadapi yaitu kurangnya motivasi dari atasan sehingga untuk menyelesaikan pekerjaan pegawai sering merasa tidak percaya diri sehingga pekerjaan selalu tidak selesai tepat waktu. Informasi diatas tidak jauh berbeda dengan jawaban yang diberikan oleh salah satu Staff Kepegawaian. Beliau menjelaskan bahwa sekitar $20 \%$ produktivitas pegawai masih belum maksimal. Hal ini mungkin disebabkan oleh kurangnya motivasi yang di berikan sehingga pegawai dalam bekerja tidak seimbang atau tidak sama meskipun dengan jenis pekerjaan yang sama. Beliau juga menjelaskan bahwa ketidakmerataan keadaan fisik antara pegawai yang satu dengan pegawai lainnya sering menimbulkan tingkat penurunan semangat dalam bekerja yang tinggi. Beberapa pegawai sering berselisih terkait dengan pekerjaan dikantor. Hal ini menunjukkan bahwa hubungan antar pegawai masih belum baik

\subsection{Rumusan Masalah}

Berdasarkan latar belakang masalah tersebut diatas, maka yang menjadi rumusan masalah dalam penelitian ini adalah :

a. Apakah disiplin berpengaruh terhadap produktivitas kerja pegawai di Sekretariat Daerah Kota Tanjungbalai?

b. Apakah kepuasan kerja berpengaruh terhadap produktivitas kerja pegawai di Sekretariat Daerah Kota Tanjungbalai?

c. Apakah motivasi berpengaruh terhadap produktivitas kerja pegawai di Sekretariat Daerah Kota Tanjungbalai?

d. Apakah disiplin, kepuasan kerja dan motivasi berpengaruh secara simultan terhadap produktivitas kerja pegawai di Sekretariat Daerah Kota Tanjungbalai?

\subsection{Batasan Masalah}

Pembatasan masalah dilakukan agar penelitian ini lebih fokus dan spesifik pada variabel-variabel penellitian, maka batasan masalah dalam penelitian ini sebagai berikut :

a. Objek penelitian ini adalah Sekretariat Daerah Kota Tanjungbalai.

b. Subjek penelitian ini adalah pegawai Sekretariat Daerah Kota Tanjungbalai yang masih aktif bekerja.

c. Lokasi penelitian ini di Kota Tanjungbalai

d. Variabel dalam penelitian ini di batasi pada disiplin, kepuasan kerja dan motivasi terhadap produktivitas kerja pegawai di Sekretariat Daerah Kota Tanjungbalai

\subsection{Hioptesis}

Menurut Supriyanto dan Machfudz (2010:176) Hipotesis merupakan kesimpulan sementara (pernyataan) yang harus dibuktikan kebenarannya, hasil pembuktian bisa saja salah bisa saja betul. Hipotesis berfungsi sebagai pegangan sementara yang masih dibuktikan kebenarannya dan kenyataannya. Hipotesis dari penelitian ini adalah:

a. Disiplin berpengaruh positif terhadap produktivitas kerja pegawai Sekretariat Daerah Kota Tanjungbalai.

b. Kepuasan kerja berpengaruh positif terhadap terhadap produktivitas kerja pegawai Sekretariat Daerah Kota Tanjungbalai 
c. Motivasi berpengaruh positif terhadap produktivitas kerja pegawai Sekretariat Daerah Kota Tanjungbalai

d. Disiplin, kepuasan kerja dan motivasi berpengaruh positif terhadap produktivitas kerja pegawai Sekretariat Daerah Kota Tanjungbalai

\subsection{Tujuan Penelitian}

Tujuan yang hendak dicapai dalam penelitian ini yaitu:

a. Untuk mengetahui pengaruh disiplin terhadap produktivitas kerja pegawai di Sekretariat Daerah Kota Tanjungbalai.

b. Untuk mengetahui pengaruh kepuasan kerja terhadap produktivitas kerja pegawai di Sekretariat Daerah Kota Tanjungbalai.

c. Untuk mengetahui pengaruh motivasi terhadap produktivitas kerja pegawai di Sekretariat Daerah Kota Tanjungbalai.

d. Untuk mengetahui pengaruh disiplin, kepuasan kerja dan motivasi secara simultan terhadap terhadap produktivitas kerja pegawai di Sekretariat Daerah Kota Tanjungbalai.

\subsection{Metode Penelitian}

\subsection{Populasi}

Populasi adalah wilayah generalisasi yang terdiri atas subjek atau objek yang mempunyai kualitas dan karakteristik tertentu yang ditetapkan oleh peneliti untuk dipelajari dan kemudian ditarik kesimpulannya, Sugiono (2013 :80). Dalam penelitian ini yang menjadi populasi penelitian adalah seluruh pegawai
Sekretariat Daerah Kota Tanjungbalai yang berjumlah 37 orang dan dapat dijelaskan dengan kerangka populasi sebagai berikut :

Tabel 1 Kerangka Populasi Berdasarkan

Jabatan Thn. 2020
\begin{tabular}{|r|l|c|}
\hline No & Jabatan & Jlh \\
\hline 1 & Kasubag & 3 \\
\hline 2 & Staff & 18 \\
\hline 3 & Honorer & 16 \\
\hline Jumlah & $\mathbf{3 7}$ \\
\hline
\end{tabular}

Sumber: Sekretariat Daerah Kota Tanjungbalai. 2020

\subsection{Sampel}

Sampling Sampel adalah bagian dari populasi yang sengaja dipilih oleh peneliti untuk diamati, sehingga sampel ukurannya lebih kecil dibandingkan populasi dan berfungsi sebagai wakil dari populasi ( Nurhayati, 2012 : 36 ). Teknik pengambilan sampel dalam penelitian ini adalah total sampling. Total sampling adalah teknik pengambilan sampel dimana jumlah sampel sama dengan populasi, Sugiyono (2010; 130). Alasan mengambil total sampling karena menurut Sugiyono jumlah populasi yang kurang dari 100 seluruh populasi dijadikan sampel penelitian semuanya Dengan teknik penarikan sampel secara Total Sampling maka sampel dalam penelitian ini adalah seluruh populasi yang dijadikan sampel yaitu pegawai Sekretariat Daerah Kota Tanjungbalai sebanyak 36 orang. Karena 1 orang Peniliti sebagai Kasubag Umum tidak ikut di teliti dalam penelitian ini.

Tabel 2. Kerangka Sampel Berdasarkan Jabatan Thn. 2020

\begin{tabular}{|r|l|c|c|c|}
\hline No & Jabatan & Jlh Populasi & Jlh Sampel & Keterangan \\
\hline 1 & Kasubag & 3 & 2 & $\begin{array}{c}\text { 1 Orang peneliti } \\
\text { tidak ikut di teliti }\end{array}$ \\
\hline 2 & Staff & 18 & 18 & Diteliti \\
\hline 3 & Honorer & 16 & 16 & Diteliti \\
\hline \multicolumn{2}{r|r|}{ Jumlah } & $\mathbf{3 7}$ & $\mathbf{3 6}$ & \\
\hline
\end{tabular}

Sumber: Sekretariat Daerah Kota Tanjungbalai. 2020

\subsection{Uji Normalitas}

Pengujian normalitas data bertujuan untuk melihat normal tidaknya sebaran data yang akan dianalisis. Model regresi yang baik adalah distribusi normal atau mendekati normal. Untuk melihat normalitas data ini digunakan pendekatan grafik yaitu Normality Probability Plot.
Deteksi normalitas dengan melihat penyebaran data (titik) pada sumbu diagonal dari grafik. Menurut Santoso (2014:214), dasar pengambilan keputusan adalah:

a. Jika data menyebar disekitar garis diagonal dan mengikuti arah garis diagonal, maka model regresi memenuhi asumsi normalitas. 
b. Jika data menyebar jauh dari garis diagonal dan atau tidak mengikuti arah garis diagonal, maka model regresi tidak memenuhi asumsi normalitas. Pada output SPSS versi 24.00 bagian normal P-P Plot of Regresion Standardized Residual, dapat dijelaskan bahwa data-data (titik-titik) cenderung lurus mengikuti garis diagonal sehingga data dalam penelitian ini cenderung berdistribusi normal, seperti terlihat pada gambar dibawah ini.

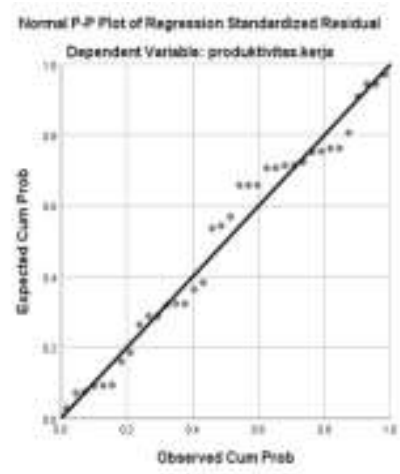

Gambar 1. Normalitas Data

\subsection{Uji Multikolinearitas}

Pengujian multikolinearitas dilakukan untuk melihat apakah pada model regresi ditemukan adanya korelasi antara variabel bebas. Jika terjadi korelasi, maka dinamakan terdapat problem multikolinearitas. Cara mendeteksinya adalah dengan melihat nilai Variance Inflation Factor (VIF). Menurut Santoso (2014:203), pada umumnya jika VIF lebih besar dari 5, maka variabel bebas tersebut mempunyai persoalan multikolinearitas dengan variabel bebas lainnya.

Pada ouput SPSS bagian Coefficient, semua angka VIF berada dibawah 5, hal ini menunjukan tidak terjadi multikolinearitas, seperti dapat dilihat pada tabel dibawah ini.

Tabel 3. Uji Multikolinearitas

\begin{tabular}{|c|c|c|c|}
\hline \multicolumn{4}{|c|}{ Coefficients $^{\mathrm{a}}$} \\
\hline \multirow{2}{*}{\multicolumn{2}{|c|}{ Model }} & \multicolumn{2}{|c|}{ Collinearity Statistics } \\
\hline & & Tolerance & VIF \\
\hline \multirow{4}{*}{1} & (Constant) & & \\
\hline & disiplin & .772 & 1.295 \\
\hline & kepuasan.kerja & .882 & 1.134 \\
\hline & motivasi & .735 & 1.360 \\
\hline
\end{tabular}

\subsection{Uji Heteroskedastisitas}

Pengujian heteroskedastisitas bertujuan untuk melihat apakah dalam sebuah model regresi terjadi ketidaksamaan varians dari residual yang merupakan suatu pengamatan ke pengamatan yang lainnya. Jika varians dari residual yang merupakan suatu pengamatan ke pengamatan yang lain bernilai tetap, maka hasil data disebut homoskedastisitas dan jika varians berbeda atau bernilai tidak tetap maka disebut heteroskedastisitas. Model regresi yang baik adalah model yang bernilai tetap atau homoskedastisitas atau tidak terjadi heteroskedastisitas.

Deteksi heteroskedastisitas dilakukan dengan cara melihat ada tidaknya pola tertentu pada data yang diolah. Menurut Santoso (2014:208), dasar pengambilan keputusannya adalah:

a. Jika pola tertentu seperti titik-titik yang ada membentuk suatu pola tertentu yang teratur, maka terdapat situasi heteroskedastisitas.

b. Jika tidak ada pola yang jelas, serta titiktitik menyebar diatas dan dibawah angka nol pada sumbu Y, maka tidak terjadi heteroskedastisitas.

Pada output SPSS dibagian Scatrerplot, terlihat titk-titik menyebar secara acak, tidak membentuk sebuah pola tertentu yang jelas, serta tersebar baik diatas maupun dibawah angka nol pada sumbu Y. Hal ini berarti tidak terjadi heterskedastisitas pada model regresi, sehingga model regresi layak dipakai. Pola Scatterplot dapat dilihat pada gambar dibawah ini.

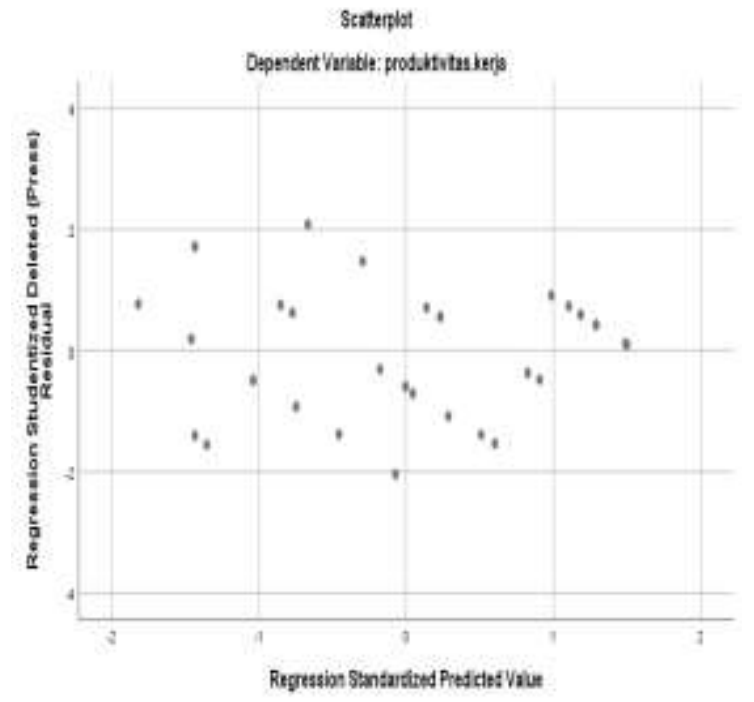

Gambar.2. Uji Heteroskedastitas 


\section{Evaluasi Data ( Analisa Regresi Linier Berganda ) \\ 3.1 Pengujian Hipotesis}

Dalam evaluasi data ini penulis akan melakukan pengujian hipotesis, baik secara partial ataupun secara simultan. Selanjutnya untuk mempermudah dalam evaluasi data ini, maka penulis mencari niali-nilai yang dibutuhkan dengan menggunakan perangkat lunak komputer yaitu program SPSS V.24.00 for windows dengan hasil data sebagai berikut:

Tabel 4.Hasil Uji Statistik Keofesien Regresi

\begin{tabular}{|c|c|c|c|c|c|c|}
\hline \multicolumn{7}{|c|}{ Coefficients $^{\mathbf{a}}$} \\
\hline \multirow{2}{*}{\multicolumn{2}{|c|}{ Model }} & \multicolumn{2}{|c|}{$\begin{array}{l}\text { Unstandardized } \\
\text { Coefficients }\end{array}$} & \multirow{2}{*}{$\begin{array}{c}\begin{array}{c}\text { Standardized } \\
\text { Coefficients }\end{array} \\
\text { Beta }\end{array}$} & \multirow[t]{2}{*}{$\mathrm{t}$} & \multirow[t]{2}{*}{ Sig. } \\
\hline & & B & Std. Error & & & \\
\hline \multirow[t]{4}{*}{1} & (Constant) & 2.155 & 5.097 & & .423 & .675 \\
\hline & disiplin & .301 & .095 & .342 & 3.163 & .003 \\
\hline & kepuasan.kerja & .313 & .098 & .324 & 3.205 & .003 \\
\hline & motivasi & .397 & .099 & .445 & 4.022 & .000 \\
\hline
\end{tabular}

a. Dependent Variable: produktivitas. kerja

Berdasarkan table 4 diatas dapat dibuat persamaan regresi sebagai berikut: $\mathrm{Y}=\mathrm{a}+$ $\mathrm{b} 1 \mathrm{X} 1+\mathrm{b} 2 \mathrm{X} 2+\mathrm{b} 3 \mathrm{X} 3+\varepsilon$

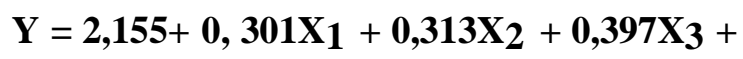

$\varepsilon$

Persamaan diatas dijelaskan bahwa koefesien disiplin mempunyai nilai positif yaitu 0,301, hal ini menunujukan bahwa variabel disiplin mempunyai pengaruh positif terhadap produktivitas kerja pegawai.

Berdasarkan persamaan diatas bahwa koefesien kepuasan kerja memiliki nilai positif yaitu 0,313 . Hal ini menunjukan bahwa variabel kepuasan kerja mempunyai pengaruh positif terhadap produktivitas kerja pegawai.

Berdasarkan persamaan diatas bahwa koefesien motivasi juga memiliki nilai positif yaitu 0,397 . Hal ini menunjukan bahwa variabel motivasi juga mempunyai pengaruh positif terhadap produktivitas kerja pegawai.

\subsection{Pengujian Secara Simultan (Uji F)}

Untuk melihat hasil seberapa besar pengaruh yang di berikan variabel independen terhadap dependen secara simultan ( bersamasama ) pada penelitian ini maka dapat di jelaskan pada tabel di bawah ini :

Tabel 5. Hasil Uji Statistik Secara Simultan

\begin{tabular}{|c|c|c|c|c|c|c|}
\hline \multicolumn{7}{|c|}{ ANOVA $^{\mathrm{a}}$} \\
\hline \multicolumn{2}{|c|}{ Model } & Sum of & df & Mean Square & & Sig. \\
\hline \multirow{3}{*}{1} & Regression & 37.389 & 3 & 12.463 & 26.296 & $000^{b}$ \\
\hline & Residual & 15.167 & 32 & .474 & & \\
\hline & Total & 52.556 & 35 & & & \\
\hline \multicolumn{7}{|c|}{ a. Dependent Variable: produktivitas.kerja } \\
\hline \multicolumn{7}{|c|}{ b. Predictors: (Constant), motivasi, kepuasan.kerja, disiplin } \\
\hline
\end{tabular}

Pada tabel 5. diatas terlihat bahwa nilai Fhitung adalah 26,296 dan nilai signifikansi 0,000. Diketahui nilai Ftabel dengan tingkat kepercayaan $95 \% \quad(\alpha: 0,05)$ adalah 2,840. Oleh karena itu nilai Fhitung > Ftabel ( 26,296 $>2,840$ ) maka $\mathrm{H}_{\mathrm{O}}$ ditolak dan menerima hipotesis dalam penelitian ini yaitu bahwa disiplin, kepuasan kerja dan motivasi berpengaruh positif dan signifikan terhadap produktivitas kerja pegawai Sekretariat Daerah Kota Tanjungbalai sebesar 26,296.

\subsection{Pengujian Secara Parsial (Uji t)}


Tabel 6. Hasil Uji Parsial Variabel X Terhadap Y

\begin{tabular}{|c|c|c|c|c|c|c|}
\hline \multicolumn{7}{|c|}{ Coefficients $^{\mathbf{a}}$} \\
\hline \multirow{2}{*}{\multicolumn{2}{|c|}{ Model }} & \multicolumn{2}{|c|}{$\begin{array}{l}\text { Unstandardized } \\
\text { Coefficients }\end{array}$} & \multirow{2}{*}{$\begin{array}{r}\begin{array}{c}\text { Standardized } \\
\text { Coefficients }\end{array} \\
\text { Beta } \\
\end{array}$} & \multirow[t]{2}{*}{$\mathrm{t}$} & \multirow[t]{2}{*}{ Sig. } \\
\hline & & B & Std. Error & & & \\
\hline \multirow[t]{4}{*}{1} & (Constant) & 2.155 & 5.097 & & .423 & .675 \\
\hline & disiplin & .301 & .095 & .342 & 3.163 & .003 \\
\hline & kepuasan.kerja & .313 & .098 & .324 & 3.205 & .003 \\
\hline & motivasi & .397 & .099 & .445 & 4.022 & .000 \\
\hline
\end{tabular}

a. Dependent Variable: produktivitas. kerja

\subsubsection{Pengaruh Disiplin Terhadap \\ Produktivitas Kerja}

Untuk mengetahui secara partial pengaruh disiplin terhadap produktivitas kerja pegawai dapat dilihat pada tebel 6 diatas. Berdasarkan tabel tersebut diperoleh nilai thitung sebesar 3,163 dan nilai signifikansi 0,003 . Sedangkan nilai tabel pada tingkat kepercayaan 95\% ( $\alpha: 0,05)$ adalah 2,021. Oleh karena itu nilai thitung > tabel $(3,163$ $>$ 2,021) maka $\mathrm{H}_{\mathrm{O}}$ ditolak dan menerima hipotesis dalam penelitian ini yaitu disiplin secara parsial berpengaruh positif terhadap produktivitas kerja pegawai Sekretariat Daerah Kota Tanjungbalai sebesar 3,163.

\subsubsection{Pengaruh Kepuasan Kerja Terhadap Produktivtas Kerja}

Untuk mengetahui secara partial pengaruh kepuasan kerja terhadap produktivitas kerja pegawai, dapat dilihat pada tebel 6 diatas. Berdasarkan tabel tersebut diperoleh nilai thitung sebesar 3,205 dan nilai signifikansi 0,003 . Sedangkan nilai tabel pada tingkat kepercayaan 95\% $(\alpha: 0,05)$ adalah 2,021. Oleh karena itu nilai thitung $>$ tabel $(3,203>$ 2,021 ) maka $\mathrm{H}_{\mathrm{O}}$ ditolak dan menerima hipotesis dalam penelitian ini yaitu kepuasan kerja secara parsial berpengaruh positif terhadap produktivitas kerja pegawai
Sekretariat Daerah Kota Tanjungbalai sebesar 3,203 .

\subsubsection{Pengaruh Motivasi Terhadap Produktivitas Kerja}

Untuk mengetahui secara parsial pengaruh motivasi terhadap produktivitas kerja pegawai , dapat dilihat pada tebel 6 diatas. Berdasarkan tabel tersebut diperoleh nilai thitung sebesar 4,022 dan nilai signifikansi 0,000 . Sedangkan nilai tabel pada tingkat kepercayaan $95 \%(\alpha: 0,05)$ adalah 2,021. Oleh karena itu nilai thitung > tabel ( 4,022 $>$ 2,021 ) maka $\mathrm{H}_{\mathrm{O}}$ ditolak dan menerima hipotesis dalam penelitian ini yaitu variabel motivasi secara parsial berpengaruh positif terhadap produktivitas kerja pegawai Sekretariat Daerah Kota Tanjungbalai sebesar 4,022 .

\subsection{Uji Koefisien Determinasi $\left(\mathbf{R}^{2}\right)$}

Uji determinan adalah uji yang dilakukan untuk mengetahui seberapa besar pengaruh variabel independent ( disiplin, kepuasan kerja dan motivasi ) terhadap variabel dependent (produktivitas kerja ). Untuk melihat hasil uji determinan maka dapat diketahui nili $\mathrm{R}$ Square atau koefesien determinasi dan dapat dilihat dibawah ini.

Tabel 7. Model Summary

\begin{tabular}{|l|r|r|r|r|r|r|}
\hline \multicolumn{7}{|c|}{ Model Summary } \\
\hline Model & $\mathrm{R}$ & R Square & $\begin{array}{l}\text { Adjusted R } \\
\text { Square }\end{array}$ & & $\begin{array}{l}\text { Std. Error of } \\
\text { the Estimate }\end{array}$ & \multicolumn{2}{|c|}{ Change Statistics } \\
\cline { 4 - 6 } & & & $\begin{array}{l}\text { R Square } \\
\text { Change }\end{array}$ & $\begin{array}{c}\text { F } \\
\text { Change }\end{array}$ \\
\hline 1 & .843 a & .711 & .684 & .68844 & .711 & 26.296 \\
\hline a. Predictors: (Constant), motivasi, kepuasan.kerja, disiplin & & \\
\hline b. Dependent Variable: produktivitas.kerja \\
\hline
\end{tabular}


Nilai R Square pada tabel 7. diatas adalah 0,711 . Hal ini menunjukan bahwa $71,10 \%$ variabel produktivitas kerja pegawai Sekretariat Daerah Kota Tanjungbalai dapat di jelaskan oleh variabel disiplin, kepuasan kerja dan motivasi sisanya sebesar $28,90 \%$ di pengaruhi oleh variabel lain yang tidak ikut di teliti.

\section{Kesimpulan}

a. Disiplin secara parsial berpengaruh positif terhadap produktivitas kerja pegawai Sekretariat Daerah Kota Tanjungbalai

b. Kepuasan kerja secara parsial berpengaruh positif terhadap produktivitas kerja pegawai Sekretariat Daerah Kota Tanjungbalai

c. Motivasi secara parsial berpengaruh positif terhadap produktivitas kerja pegawai Sekretariat Daerah Kota Tanjungbalai

d. Disiplin, kepuasan kerja dan motivasi berpengaruh positif dan signifikan terhadap produktivitas kerja pegawai Sekretariat Daerah Kota Tanjungbalai

e. Diketahui nilai R Square adalah 0,711. Oleh sebab itu maka sebesar 71,10\% variabel produktivitas kerja pegawai Sekretariat Daerah Kota Tanjungbalai dapat di jelaskan oleh variabel disiplin, kepuasan kerja dan motivasi sisanya sebesar $28,90 \%$ di pengaruhi oleh variabel lain yang tidak ikut di teliti

\section{DAFTAR PUSTAKA}

Abdul Hafiz Tanjung. 2014. Akuntansi, Transparansi, dan Akuntabilitas Keuangan Publik. Yogyakarta: BPFE UGM.

Abdurrahmat, Fathoni. 2016. Manajemen Sumber Daya Manusia. Bandung: Rineka Cipta.

Achmad, dkk. 2010. Manajemen

Pemasaran (Ringkasan Praktis, Teori, Aplikasi \& Tanya Jawab). Bandung: Linda Karya.

As'ad, Moh. 2013. Psikologi Industri, Seri

Ilmu Sumber Daya Manusia, Liberty, Jakarta.

Azwar, S. 2017 . Reliabilitas Dan Validitas. Yogyakarta: Pustaka Pelajar. Bambang Riyanto. 2016 . Dasar-dasar Pembelanjaran Perusahaan. Yogyakarta : BPFE.
Chukwuna, Edwin Maduka, and Okafur,Obiefuna. 2014. Effect of Motivation on Employee Productivity: A Study of Manufacturing Companies in Nnewi. International Journal of Managerial and Research, Vol. 2, Issue 7, 137-147.

Crook and Morrison, K. 2011. Research Methods in Education (7th Ed). London: Routledge.

Edy, Sutrisno. 2011. Manajemen Sumber Daya Manusia. Penerbit: Jakarta, Kencana. Eko Widodo, Suparno. 2015." Manajemen Pengembangan Sumber Daya Manusia”. Yogyakarta: Pustaka Pelajar Engko, Cecilia. 2018. "Pengaruh Kepuasan Kerja Terhadap Kinerja Individual Dengan Self Esteem dan Self Efficacy Sebagai Variabel Intervening". Jurnal Bisnis dan Akuntansi Vol. 10, No. 1

Hasibuan, Malayu. 2016. Manajemen Sumber Daya Manusia. Jakarta: Penerbit Bumi Aksara.

Kreitner, Robert, and Kinicki, Angelo, 2011, Perilaku Organisasi, Dalam: Early Suandy (penterjemah), Jakarta: Salemba Empat.

Kusnendi, 2013, Analisis Jalur Konsep dan Aplikasi Program SPSS. Universitas. Pendidikan Indonesia.

Mangkuprawira, 2011, Manajemen Sumber Daya Manusia, Strategi, Ghalia Indonesia, Jakarta.

Miranty Nurhayati. 2012. Analisis Pengaruh Kinerja Keuangan, Good Corporate Governance dan Corporate Social Responsibility Terhadap Nilai Perusahaan yang Terdaftar Dalam LQ45 pada Tahun 2012

Moorhead dan Griffin. 2013. Perilaku Organisasi. Jakarta: Salemba Empat. Nasution, 2011, Metode Research, Bumi Aksara, Jakarta.

Riggio, E. R. 2013. Introduction to Industrial/Organizational Psychology (6th ed). New Jersey: Pearson Education

Rivai, 2011, Manajemen Sumber Daya Manusia untuk Perusahaan: Dari. Teori ke Praktik, Raja Grafindo, Jakarta.

Robbins, 2011, Perilaku Organisasi, Salemba Empat, Jakarta.

Saksono, Slamet. 2017. Manajemen Kepegawaian. Jogjakarta: kanisius Schermerhorn, John R. 2015 
Management, 12th ed. New Jersey: John Wiley \& Sons, Inc.

Sedarmayanti, 2013, Manajemen Sumber Daya Manusia, Bandung: Refika Aditama.

Simamora, H. 2014, Manajemen Sumber Daya Manusia, Edisi Kedua, Sekolah Tinggi Ilmu Ekonomi (YKPN), Yogyakarta. Sinungan, Muchdarsyah . 2015

Produktivitas Apa dan Bagaimana. cetakan ke 9 . Jakarta : Bumi Aksara

Sofyandi dan Garniwa. 2017. Perilaku Organisasional. Edisi Pertama. Yogyakarta: Graha Ilmu.

Sondang P . Siagian, 2013, Manajemen Sumber daya Manusia, Bumi aksara, jakarta.

2011. Manajemen Sumber Daya

Manusia. Jakarta: Bumi Aksara. Jakarta.

Sugiyono, 2013, Statistika Untuk

Penelitian, Cetakan Ketujuh, Alfabeta, Bandung.

Sumodiningrat, Gunawan. 2011. Membangun Perekonomian Rakyat, (Yogyakarta: Pustaka Pelajar ).

Supriyanto, Achmad Sani. dan Masyhuri Machfudz. 2010. Metodologi Riset: Manajemen Sumberdaya Manusia. Malang: UIN-Maliki Press.

Wibowo. 2013. Perilaku dalam Organisasi. Jakarta: PT. Raja Grafindo Persada

Widodo, Trenggono, dkk. 2018. "Analisis Pengaruh Gaya Kepemimpinan, Disiplin Kerja dan Pelatihan Kerja terhadap Kinerja Karyawan di PT Telkom Indonesia Cabang Batam". Jurnal Industri Kreatif (JIK), Vol. 2 No.1 ISSN : 2597-8950.

Winardi,2010, Manajemen Prilaku Organisasi, Edisi Revisi, Jakarta:Kencana. Wursanto, IG. 2015. Manajemen Kepegawaian. Yogyakarta: Kanisius 